\title{
Politically Charged Records: A Case Study with Recommendations for Providing Access to a Challenging Collection
}

Valerie Harris and Kathryn Stine

\begin{abstract}
A b stract
In the months leading up to the 2008 presidential election, a collection of organizational records held by the Special Collections Department of the University of Illinois at Chicago became a politically charged source of public scrutiny, and the department's role in providing access to the collection became one of the top library stories of the year. This case study relates how the department implemented new collections management policies and procedures and developed an attuned sensitivity to balancing donor obligations with researcher needs in the wake of a public relations crisis.
\end{abstract}

$\mathrm{W}$ ith increased accessibility comes increased scrutiny of archival access systems, and with scrutiny comes the possibility of grand-scale exposure of the weaknesses in the systems. The University of Illinois at Chicago, University Library, Special Collections Department (UIC Special Collections), experienced such a crisis when, in August 2008, a remote researcher requested to view what seemed an innocuous collection of organizational records held in the manuscripts division of the department. The staff

(c) Valerie Harris and Kathryn Stine.

This case study was adapted from a presentation at the Midwest Archives Conference Annual Meeting, St. Louis, Missouri, 1 May 2009. The authors wish to thank John Cullars, Steve Wiberley, and Ann Weller, all of the University of Illinois at Chicago, University Library, for their smart and thoughtful comments on the many drafts of this paper as it made its way from PowerPoint presentation to a completed manuscript. 
quickly discovered a host of ethical, legal, and public relations issues during what became a concentrated, though relatively short-lived, media frenzy. This intensely challenging experience also became an opportunity for the department to implement a comprehensive collections management overhaul and more thorough control over legacy collection documentation. Through this challenge, UIC Special Collections staff members have become more deeply engaged in nearly all levels of UIC's archival program activities, from donor relations to reference services.

This paper recounts the discovery, temporary closing, and subsequent active research use of the Chicago Annenberg Challenge (CAC) records as a case study relating how the department implemented new collections management policies and procedures, and developed an attuned sensitivity to balancing donor obligations with researcher needs in the wake of a universitywide public relations crisis.

The activities involved in acquiring, accessioning, processing, and making a complicated/contentious collection accessible intersect with several contemporary developments in archival management. We discuss these trends and how UIC Special Collections adapted or changed its practices. We also consider implications for archivists working in similar situations. This study examines not just how the media portrayed an association between presidential candidate Barack Obama and UIC education professor William Ayers as an instance of a potential head-of-state allegedly "palling around with a terrorist,"1 but also how UIC was caught up in this sensational news story, leading to insinuations that archivists and administrators were part of a cover-up scandal.

Most archival repositories, UIC included, document negotiations and decisions made with donors through deeds or correspondence, but sometimes formal agreements fall through the cracks. While a lack of institutional memory is not altogether unusual, this particular lack of legacy documentation ended up contributing to a public relations challenge, leaving current staff to create their own path through critical access and public relations decisions. This story should give archivists pause to think about those handshake agreements that can come back to haunt an institution years later.

\footnotetext{
1 Kate Phillips, "Palin: Obama Is 'Palling Around with Terrorists,'” The Caucus: The Government and Politics Blog of The Times, 4 October 2008, http://thecaucus.blogs.nytimes.com/2008/10/04/ palin-obama-is-palling-around-with-terrorists/, accessed 5 July 2011.
} 


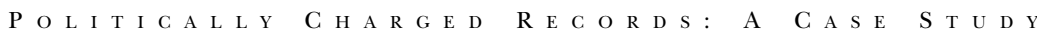

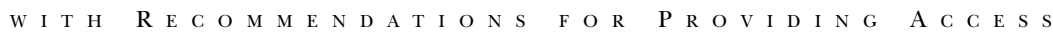

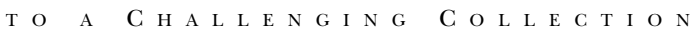

\section{Chicago Annenberg Challenge (CAC) Records \\ B a ckground}

In 1993, the Annenberg Foundation, a philanthropic organization based in Philadelphia, announced a $\$ 500$ million program to support school reform in public schools across the nation. The foundation invited cities to submit proposals for grant funding "to stimulate educational innovation and collaboration in their public school districts." 2 William Ayers, an elementary education scholar and professor in the College of Education at UIC, known also for his involvement in the Vietnam War-era political group the Weather Underground, was one of three co-authors of the proposal that secured Chicago as part of the Annenberg Foundation's "challenge to the nation." As one of eighteen chosen sites, Chicago received $\$ 49.2$ million to conduct research on improving its schools.

The award is known as the Chicago Annenberg Challenge, and Ayers remained actively involved in the project during its life from 1995 to 2001. Barack Obama, then a practicing attorney and lecturer at the University of Chicago Law School, initially led the CAC board of directors from 1995 to 1999 and continued his board service through 2001. The CAC raised funds from public and private sources in Chicago that more than doubled the initial Annenberg Foundation grant, and, in turn, distributed grant funding to hundreds of Chicago-area schools and community organizations.

According to departmental correspondence, toward the end of the CAC's work in 2001, the executive director of the CAC board sought an appropriate repository to take custody of and provide access to its records of continuing usefulness. CAC sought an agreement under which its staff would have access to the records during the transition time between the organization's concluding activities and the acquiring repository's processing of the records for public access. Additionally, CAC was concerned about confidentiality for records dealing with active grants, some of which included examples of student work, and about copyright of unpublished reports and studies.

Discovering the Records

The CAC records had been acquired, minimally processed by a contracted employee, and made public in 2002. In the late summer of 2008, there was little reason to anticipate that this collection, deposited, described, and unused, ${ }^{3}$

2 CAC draft administrative history found in CAC records collection file, UIC Special Collections.

3 According to the UIC Special Collections annual reports to the university librarian, there was no recorded use of the CAC records between 2002 and 2007. 
would become a politically charged source of public scrutiny and generate one of the top library stories of the year. ${ }^{4}$ But, in the months leading up to the 2008 U.S. presidential election, political analysts, bloggers, journalists, campaign workers, and interested citizens scrutinized every aspect of the candidates' lives, personal and professional, in many cases to reveal sensational stories about them.

The CAC records came under intense scrutiny because of what they might reveal about Barack Obama's relationship to Bill Ayers when both were members on the CAC board. Some hoped to show unequivocally a close working relationship between Obama and Ayers, thereby refuting candidate Obama's statement that Ayers was "just a guy in [his] neighborhood." ${ }^{5}$ However, before UIC Special Collections staff even knew these connections were of interest, both a researcher seeking access to the CAC records and the CAC representative who had originally arranged the donation of the records to the library contacted the department. Once the CAC records were "discovered," staff at UIC Library experienced more than two weeks of national notoriety. The potential for a political bombshell that could possibly sway the national election transformed the CAC records from a resource for those interested in education reform to a newsworthy collection of national interest.

In early August 2008, Stanley Kurtz, a columnist for the National Review Online (NRO), contacted UIC Special Collections reference staff to make an appointment to research the CAC records. ${ }^{6}$ A few days later, staff emailed Kurtz a scanned inventory of the collection, told him of a related collection in the University Archives, and arranged a research appointment. A near-simultaneous call from the former CAC representative prompted subsequent discovery that no finalized deed of gift was in the collection file. Compounding the confusion, staff soon discovered among the sparse documentation of the collection that the CAC board, in donating the records, wanted to maintain the privacy of public school students participating in CAC-funded programs and individual donors to the CAC fund. Staff then found that this private information had not been removed or redacted during processing. Because of these custody and privacy issues, the head of UIC Special Collections, in consultation with the university librarian and other UIC administrators, decided to close the CAC records temporarily to address these concerns.

Kurtz kept his research appointment in spite of the CAC records closure and reviewed relevant related material in the office of the chancellor records in

4 "Year in Review: Top 10 Library Stories of 2008," American Libraries 39, no. 11 (2008): 38-41.

5 "Transcript: Obama and Clinton Debate," ABC News, http://abcnews.go.com/Politics/ DemocraticDebate/story?id=4670271\&page=2, accessed 30 June 2010.

${ }_{6}$ This paper includes patron information that would otherwise be confidential because the patron himself made his interactions with UIC public through his blog posts, National Review Online, "Stanley Kurtz," http:/ / www.nationalreview.com/author/56399, accessed 5 July 2011. 


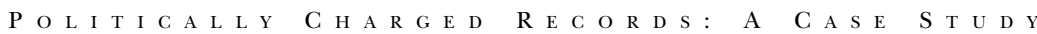

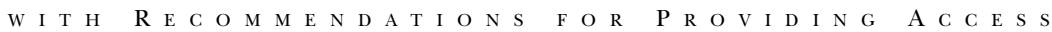

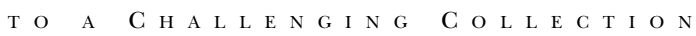

the UIC University Archives instead. Shortly after his visit, he wrote an editorial on the NRO blog denouncing the closure of the CAC organizational records and insinuating that the UIC Special Collections and Bill Ayers colluded to cover up connections that might damage the Obama presidential bid. ${ }^{7}$

The UIC Library became a catalyst in the latest round of election year sparring between the left and right wings of American political thought. During UIC Library's own "days of rage," the library received hundreds of questioning, angry, and sometimes threatening ${ }^{8}$ calls and emails that affected staff beyond Special Collections. The swiftness of the reaction against UIC Library's decision to close the CAC records illustrates the immediacy of the online world in which libraries and archives now reside.

Archivists are in the business of making collections available to researchers, and, increasingly, our goals regarding accessibility have come to address researchers' expectations of ubiquitous online discovery and access. The emergence of Encoded Archival Description (EAD) twelve years ago supported archivists broadening access to their collections, and now many repositories have successfully mounted online finding aids. Beyond simply posting finding aids, many archivists have also worked to get their collection descriptions "in the flow," searchable not just on their own repositories' websites but by meeting researchers where they are already looking, namely search engines and social media sites. Additionally, since the publication of Greene and Meissner's watershed 2005 article advocating minimal processing, ${ }^{10}$ many archivists have also sought to expedite access to collections that have long lingered in processing backlogs by balancing adequate description with the promise of more immediate access.

Being easily and quickly found, however, means that an archival repository needs to be vigilant about the many questions that can come up regarding access to a given collection at the point of acquiring and processing it, including issues of privacy and ownership. When archivists have the luxury of time to process collections and mediate users' queries, they can evaluate descriptions of collections for matters of privacy and ownership before presenting the

7 Stanley Kurtz, "Chicago Annenberg Challenge Shutdown?,” National Review Online, 18 August 2008, http://www.nationalreview.com/articles/225348/chicago-annenberg-challenge-shutdown/stanleykurtz?page=1, accessed 5 July 2011.

8 The debate included heated discussion of the events and their professional impact on the Archives and Archivists listserv.

9 Ricky Erway and Jennifer Schaffner, "Shifting Gears: Gearing Up to Get Into the Flow," report by OCLC Programs and Research (2007), http://www.oclc.org/programs/publications/reports/ 2007-02.pdf, accessed 5 July 2011; and Lorcan Dempsey, "In the Flow," Lorcan Dempsey's Weblog on Libraries, Services and Networks, 24 June 2005, http:/ / orweblog.oclc.org/archives/000688.html, accessed 5 July 2011.

${ }^{10}$ Mark A. Greene and Dennis Meissner, "More Product, Less Process: Revamping Traditional Archival Processing," American Archivist 68, no. 2 (Fall/Winter 2005): 208-63. 
collections to the user. In an online environment, however, users find relevant collections within seconds of submitting a search term. Unmediated discovery can expose instances where clear title to the relevant collection is in question, when legacy description did not adequately protect sensitive information, or when legacy arrangement did not physically isolate restricted material. In such cases, the archivist may unwittingly betray professional norms.

Better management of UIC's collections, from acquisition through arrangement and description, might have prevented this chain of misunderstandings, and the temporary closing of the CAC records would not have been a chapter in the story of the Obama-Ayers connection.

\section{Impact on Stakeholders}

After closing the CAC records, UIC Special Collections staff consulted university lawyers about appropriate steps to take to meet the needs of both researchers and the donor. After evaluating the collection files, accession records, and the CAC records themselves, the university lawyers discovered documentation of the CAC board's intention to donate. The CAC board had voted overwhelmingly to approve the donation of its records to the UIC Library in meeting minutes on file in the collection. ${ }^{11}$

With the custody issue settled, tackling the problem of sensitive information in the records remained. Legal counsel developed a protocol for review of private information contained in the CAC records to guide Special Collections staff in preparing the collection for its re-opening to researchers. Understanding the urgency with which researchers were awaiting the collection's re-opening, staff worked furiously to scour the entire seventy-linear-foot collection, flagging any records that included Social Security, bank account, and credit/debit card numbers; personal income tax, personnel, and medical records; as well as any means of linking student names with test scores or grades. These records were then redacted following a "redact, replace, but preserve"12 approach. This entire process resulted in ultimately just one linear foot of records being redacted, and UIC Special Collections re-opened the CAC records fourteen days after their closure.

As anticipated, upon opening the records, department staff was confronted with a new group of researchers: reporters, newscasters, and campaign strategists, who are typically not encountered in the reading room, or at least not

\footnotetext{
${ }^{11}$ Chicago Annenberg Challenge Records, 1996-2001, Box 118, University of Illinois at Chicago Library, Special Collections and University Archives Department.

${ }^{12}$ Our steps were to first photocopy sensitive documents, then redact Social Security numbers, personal income records, student names and test scores, and other identifying information from the photocopies. We then marked the copies as such to clarify that they are not the originals, and, finally, isolated the originals from the circulating collection.
} 
in such a high concentration. The majority of the media professionals visiting the collection seemed to have scant experience with conducting research in an archives setting. The requisite set of procedures and protocols, including access regulations, photocopy policies, and a respect for the confidentiality of patron circulation records seemed new and unfamiliar to these researchers. The reporters were covering a story and wanted immediate and unmediated access to any and all relevant material, to sit with their assistants and make calls from the reading room, and to see whatever it was that another reporter just saw. These challenges to the standard operating procedures of the reading room led staff to make a mental checklist of the reasons why all of those regulations are needed and to determine what weight of law and ethics would support our policies governing the use of the collections in our custody.

Staff sought to maintain the neutral, user-centered standards of archival practice and to avoid defensive, bunker-mentality interactions with these researchers. Simply put, user-centered archivists define who their users are, ask their users what they want, and develop strategies to provide users what they want, within the context of professional responsibilities. In the case of the CAC crisis, our users were media professionals unaccustomed to archival research, although imbued with a high level of confidence in their research skills. Our professional responsibilities included not only meeting the patrons' needs, but also preserving the records, abiding by the terms defined in the donor correspondence, and acknowledging and protecting the privacy rights of individuals represented in the records.

When addressing these goals, UIC staff made several accommodations: first, to meet patrons' urgency, UIC Special Collections waived the reading room capacity limit; minimized individual orientation to the research process; provided photocopies, free of charge, of all documents directly naming either Ayers or Obama; and allowed patrons to reserve up to two boxes on a first-come, first-served basis. Second, to protect and preserve the records, UIC Special Collections assigned additional staff to monitor the reading room, including a UIC police officer who was present to respond to threats. ${ }^{13}$ Finally, to protect third-party privacy, the university hired lawyers to review the CAC records and develop a protocol for securing private information. ${ }^{14}$

${ }^{13}$ After Kurtz's posts were reblogged and eventually became a topic on Rush Limbaugh's radio show, staff members library-wide were subjected to anonymous and abusive telephone calls.

${ }^{14}$ To guide decision-making, UIC Special Collections staff relied heavily on the advice offered in the excellent Navigating Legal Issues in Archives (Chicago: Society of American Archivists, 2008) by Menzi L. Behrnd-Klodt, particularly chapter 10: "Access and Privacy Issues in Archives"; Mary Jo Pugh's advice on working with different user groups and managing user expectations in Providing Reference Services for Archives and Manuscripts (Chicago: Society of American Archivists, 2005); and the "ALA/SAA Joint Statement on Access to Research Materials in Archives and Special Collections Libraries," Society of American Archivists, http://www.archivists.org/statements/ALA-SAA-Access09.asp, accessed 13 October 2010, which states "that private donors have the right to impose reasonable restrictions upon their papers," and that "[a repository's] governing access and use...must be applied and enforced equally." 
The intensive research interest in the CAC records caused UIC Special Collections staff to reconstruct the chain of events that had led us to the crisis. Through the collection file, and from the collection itself, we had learned that in December 2001, the CAC board made a unanimous decision to deposit the records with the UIC University Library Special Collections Department. Additionally, the CAC board provided funds to the university to hire a contracted worker to develop an initial container list inventory of the records. So, in 2002, a contracted processor was hired to organize and inventory the collection. Any restrictions outlined in what might have been a pending deed of gift with the UIC University Library were neither recorded nor followed in the resulting description of the collection, and details of the processing likewise were not documented.

Perhaps because the CAC records were processed "minimally," though not entirely in the spirit of "More Product, Less Process," the description of the collection that was made accessible online did not fully address the privacy or ownership concerns that temporarily arrested researcher access. In hindsight, closer communication with the donor and better documentation of this communication would likely have highlighted these significant concerns at the onset of processing. Donor communication becomes all the more critical for any archives considering minimal approaches to processing its collections. If an archivist is not going to, as a matter of course, weed or scan down to the item or subfolder level, he or she still needs to be aware of what the potential, lurking subfolder time bombs could be.

While recent professional literature, conference presentations, and blogging activity call upon archivists to be much more active in discussing processing strategies and access goals with collection donors, this ideal is not always put into practice. ${ }^{15}$ In adopting minimal processing approaches, Christine Weideman advocates that archivists be much more upfront in their conversations with donors about documenting collections. ${ }^{16}$ At a minimum, donors, who are in the best position to identify whether and where sensitive materials are in a collection, should simply be asked to provide this information to inform processing and access decisions. Ideally donors will remove, redact, or segregate sensitive materials prior to depositing their records.

When a repository undergoes significant leadership transitions, however, and donor conversations have been informal, poorly documented, or possibly nonexistent, current staff is often left to piece together the history of the deposit,

\footnotetext{
${ }^{15}$ Daniel Hartwig, "Pre-Custodial Intervention and Institutional Repositories," presentation at the Society of American Archivists' Annual Meeting, Session 502: Pre-Custodial Intervention: Let Them Do the Damn Work!, San Francisco, 24-31 August 2008.

${ }^{16}$ Christine Weideman, “Accessioning as Processing," American Archivist 69, no. 2 (2005): 274-83.
} 
the processing plan, and the intentions of the donation. Ultimately, collection files, whether they be physical, electronic, in a database, or any combination thereof, are the vital records of any repository in that they document legal transfers of ownership and rights, the core functions and activities of the repository, and, most critically for institutional memory, its decision-making processes. Collection files, which are essentially the records of collecting records, should be reviewed regularly to update donor contacts and to address any issues that raise red flags. Frank Boles, for example, asserts that "process control" information, that which is essential to guiding processing decisions, be gathered and entered into tracking systems early in the accessioning process. ${ }^{17}$

By all appearances, the CAC records inventory closely followed the arrangement of the materials as the CAC deposited them. The initial box list provided by the CAC forms the basis for the more detailed box and folder list written by the contract processor, ${ }^{18}$ which also includes notes about the scope, content, and organization of the records. And, while the inventory is quite detailed, even at times offering subfolder-level lists of document types, several omissions both in arranging and describing occured. In a perfect world, these would have been caught prior to the inventory being made accessible. For all the attention paid to item-level identification, extraneous materials (such as mailing labels and canceled checks with scant evidential value) were retained, and, conversely, materials of a sensitive, private nature (such as student names and Social Security numbers) were not redacted or removed. Further inspection of the inventory makes clear that the arrangement of the records as received from CAC was kept intact, with "see also" notes used as pointers from a run of folders just a five-folder jump away from another grouping of like materials.

Discussions and arguments regarding approaches to minimal processing abound among archivists these days, encouraging camps of both adherents and critics, with many pragmatist adopters falling somewhere in between. ${ }^{19}$ Judging from the amount of private information left in the records, it seems that processing of the CAC collection rarely went below the folder level, which

${ }^{17}$ Frank Boles, Selecting and Appraising Archives and Manuscripts (Chicago: Society of American Archivists, 2005), 147.

18 "Chicago Annenberg Challenge Records: An Inventory of the Collection at the University of Illinois at Chicago," http://www.uic.edu/depts/lib/specialcoll/services/rjd/findingaids/ChicagoAnnenbergf. html, accessed 18 November 2010.

19 "Dan Santamaria Shares Some Thoughts on the Recent MPLP Discussions," ArchivesNext, 21 August, 2009, http://www.archivesnext.com/?p=332; Dennis Meissner and Mark A. Green, "More Application while Less Appreciation: The Adopters and Antagonists of MPLP," Journal of Archival Organization 8, nos. 3-4 (2010): 174-226; Christopher J. Prom, "Optimum Access? Processing in College and University Archives," American Archivist 73, no. 1 (Spring/Summer 2010): 146-74; Colleen McFarland, "It Changed My Life: Lessons Learned from Minimal Processing," presentation at the Midwest Archives Conference (MAC) Fall Symposium on Minimal Processing, Omaha, 6-7 October 2006; Pam HackbartDean and Elizabeth Slomba, SPEC Kit 314: Processing Decisions for Manuscripts and Archives (Washington, D.C.: Association of Research Libraries, 2009). 
should provide cause for caution and reflection for any archivist implementing a minimal processing approach. ${ }^{20}$ By the processing standards UIC Special Collections now has in place, we would consider any collection that has been processed without considering privacy concerns not to be ready for researchers.

The CAC records' partially processed state and the incomplete paperwork in the collection file led to a crisis that would have lasting, ultimately positive, effects on UIC Special Collection's effectiveness as stewards of our collections, including generating new approaches to implementing processing workflows, descriptions, and access. As is probably the case for most repositories, UIC Special Collections policies and procedures regarding processing and access have rarely been challenged. Most people or organizations send their papers and records to the archives and forget about them, and users are generally happy to comply with the idiosyncrasies of archival research and the attendant rules and regulations. However, archivists must be cognizant of legal and ethical responsibilities to both donors and researchers, and when a challenge is made, it becomes vitally important to have documented policies and procedures to both share with constituents and to guide decision making. ${ }^{21}$

\section{O u t comes}

During and after the CAC incident, UIC Special Collections staff looked to the professional literature to guide our ethics in response to patron and donor requests. The triage strategies developed to address the immediate concerns of the CAC crisis would be extended to reform the department's collections management activities and subsequently positively affect the public services program.

In the case of our handling of the CAC records during their temporary closure, documents that may have been weeded out of the collection and securely destroyed were redacted rather than shredded, and redactions were favored over outright restrictions to the records concerned. These decisions were made due to the very public nature of the closure of the collection and in consideration of accusations originating in the blogosphere that challenged the

\footnotetext{
20 "Concerns have been raised about the possible release of sensitive information if archivists fail to give adequate attention to the content of materials at the folder and box levels." Carl Van Ness, "Much Ado about Paper Clips: 'More Product, Less Process' and the Modern Manuscript Repository," American Archivist 73, no. 1 (Spring/Summer 2010): 129-45.

${ }^{21}$ The library's website includes information for patrons about donating collections, "Gifts in Kind," http://library.uic.edu/about/giving-to-the-library/gifts-in-kind2, accessed 5 July 2011; policies and procedures governing the use of collections and related services are linked from the Special Collections Web page, "Manuscripts and Rare Books," http://library.uic.edu/home/collections/manuscriptsand-rare-books, accessed 5 July 2011, while the manuscript collections' processing guide is available to UIC faculty, students, and staff via the university's wiki.
} 
security and integrity of the records under the library's care. ${ }^{22}$ Rather than simply destroying old invoices and student grade reports, staff redacted these to convey to researchers the fact that nothing had been removed from the collection during its closure.

This level of scrutiny is not one that Special Collections staff would replicate in processing newly acquired collections, nor is redaction an adequate or efficient means of mitigating privacy concerns in manuscript collections. ${ }^{23} \mathrm{In}$ the wake of the CAC crisis, UIC Special Collections has adopted several new procedures to address privacy concerns that arise in administering access to both new and previously processed and accessioned collections. An intake form has been developed to capture pertinent information during initial and ongoing donor contacts with the department. This form gathers details regarding potentially sensitive records at the outset of donor relationship building. This intake information is stored on a shared server where designated staff can view and comment on a given collection's suitability for accessioning as well as on the potential issues that need to be addressed during the accessioning process. Additionally, a collections committee meets regularly to discuss such issues before deeds are negotiated and donations are brought into the repository.

To gain better control of the collections during and after accessioning, the Special Collections department head charged a task force with evaluating two open-source collection management database applications designed for archival collections: Archon and Archivist's Toolkit (AT). The task force assessed the two applications for their potential to track donors and accessions, and to support a workflow from the time a collection is donated or purchased through processing, finding aid creation and publication, and finally making it accessible to the public. The task force recommended the Archivist's Toolkit, which offers a robust set of collections management and EAD authoring tools. The Special Collections AT work group has uploaded existing EAD XML files to populate resource records and has imported legacy spreadsheet data to effectively track each accession. We are now populating all accessions and resource records with locations from the department's shelving guide.

While a computer application is certainly not a panacea that can be applied to every challenge and recordkeeping idiosyncrasy posed by managing a broad and complex range of collections, it does provide staff with a means of consolidated collections assessment. As importantly, implementing AT represents a shift in procedures, providing opportunities to re-evaluate and

${ }^{22}$ Further discussions of the archivists' ethical role in ensuring access to authentic, secure, and complete records can be found in Elena Danielson's "Ethics of Access," American Archivist 52 (Winter 1989): 52-62, including the issues surrounding Francis Lowenheim's claims against staff at the Roosevelt Presidential Library in the 1970s.

${ }^{23}$ See Menzi L. Behrnd-Klodt's Navigating Legal Issues in Archives, 112, for a discussion of the potential liability that archivists may open up in attempting to set privacy standards regarding what the public may or may not see in the collections under their care. 
reflect upon business as usual. The organic workflow implied by the software's structure and design fairly closely mirrors existing procedures in the department. Staff members have been able to customize approaches to populating records in AT and compile department-specific training materials. We are confident that documenting and relating the life cycles of the collections (prior to and during their research use under our custody) in an integrated database will aid all aspects of collections management, while still acknowledging the important role of human decision making during archival processing.

Deciding when and how to impose restrictions on any given collection will involve flexible and sensitive considerations that strike a balance between researcher access, donor wishes, applicable laws and regulations, professional guidelines, and internal norms. Certainly, no one set of procedures will suffice for all scenarios. However, Special Collections staff has developed a more nuanced and pragmatic stance regarding these issues in large part due to the many challenges brought about during the CAC crisis.

For all new acquisitions, the intake information gathered from collections donors along with specific requirements negotiated in the wording of the deed of gift are included in an AT accession record, which is then used as the basis for a processing assessment survey. Early, clear, and documented consultation with donors can now more effectively be integrated into processing procedures for each collection. Staff can now refer to a decision matrix detailing internal best practices for handling particular types of sensitive records, including social service case files and personnel, student, and health records (see Appendix 1). Staff and patrons are alerted to the presence of restricted records in a box through the new practice of applying a brightly colored sticker that includes a note about the type and duration of the restriction.

The challenges that UIC Special Collections confronted in providing access to the CAC records shed light on those areas where control over our collections needed assessment and re-evaluation. We have since become more cautious, not taking for granted that a collection file contains a complete, or even sufficient, paper trail documenting clear transfer of ownership, copyright, and restrictions and disposal decisions affecting access to information. We certainly do not always expect to find substantive evidence of donor negotiations, appraisal and processing decisions, or indications of sensitive materials within the collection. Given that more than 700 collections comprise the UIC Special Collections manuscript division, making comprehensive, retroactive updates to finding aids; contacting previous donors to confirm transfer of ownership; and conducting copyright research combine into a massive and ongoing endeavor.

UIC Special Collections staff is now employing three approaches to make collection management a bit more manageable. First, we conducted a comprehensive audit of the collection files for all accessions, whether processed 
or not, to track receipt of deeds, rights transfers, and restrictions on access and use. Second, we entered the information uncovered in this audit, along with other provenencial information for each accession, into a networked instance of AT so that any staff member can quickly and easily determine what unresolved or sensitive issues might apply to a particular collection. As newly formatted finding aids are exported from AT, updates are made to convey conditions governing access to users. In the case of collections with known, especially complex use and access restrictions, we scan deeds of gift and store them on a shared server so that reference librarians have immediate access to the original wording. Third, we have asserted greater control over identifying collections that merit increased scrutiny and may need to be re-examined to make changes to the finding aid, to reprocess certain series or subseries to handle restricted materials, or to confirm or formalize donor intentions. Examples of these include social services collections containing case files, and faculty and university department records that might contain student files.

The CAC crisis also led to a re-evaluation of processing workflows and how we provide access to collections and deliver public services. Like many other archives and special collections libraries, UIC's collections are processed to varying degrees, ranging from those with brief, donor-supplied, collection-level summaries to staff-created, folder-level inventories to "full-fledged" finding aids that reflect careful arrangement decisions and researched contextual descriptions. In general, collection descriptions available to online researchers belong to this latter category. Collection descriptions that fall short of a DACScompliant finding aid are sometimes made available online as PDF container lists but are more generally made available to patrons through mediated reference interactions by phone, by email, or in person.

The complications that arose from supplying access to an inventory, rather than a finding aid, of the CAC records did not just expose the weaknesses of internal recordkeeping but also provided an opportunity to take stock of whether and how all staff who work with patrons might have more immediate and efficient access to pertinent information regarding terms of use. Staff members are now using AT at the reading room reference desk as the single, authoritative stop to identify a collection's location, physical format, donor information, and use restrictions.

The crisis provided UIC Special Collections with the opportunity to reevaluate how we engage with and communicate professionalism to our constituents. UIC Special Collections is working toward a higher degree of transparency and user-centered service. ${ }^{24}$ An often-asked question both during and after the events of August and September 2008 was "Why don't people understand that

${ }^{24}$ For a discussion of user-driven service changes at UIC Special Collections, see Valerie Harris, "How Can I Help You?: Becoming User-Centered in Special Collections," Archival Issues 32, no. 2 (2010): 71-98. 
we are not politically motivated in the work we do as archivists?" One answer to that question may be that misunderstandings persist regarding the work archivists do and the professional standards to which we hold ourselves. If, as the literature shows, ${ }^{25}$ archivists are perceived as gatekeepers or content experts, as translators, boundary spanners, ${ }^{26}$ or mediators, ${ }^{27}$ then archivists must take a more proactive role in defining our image.

Opportunities to increase the public's understanding of the role of archivists in education and preserving the historical record are manifold. Cossette $\mathrm{N}$. Keis recommends working more closely with our colleagues in marketing, creating relationships with local media outlets to advertise collections and events, and publishing outside the professional literature. ${ }^{28}$ Advocating Archives: An Introduction to Public Relations for Archivists, ${ }^{29}$ published in 1994, provided practical ideas for archivists and special collections librarians wishing to build new audiences, but could not foresee the time when social media such as Twitter, Facebook, photo sharing sites, and blogs could be used as effective tools for that purpose and, in fact, afford immediate communication channels among the many constituents involved in archival administration and research. Beth Whittaker and Lynne M. Thomas ${ }^{30}$ show how these new technologies can connect cultural heritage sites with users who increasingly rely on nonlibrary-created tools such as Google to begin their research process. Still, those more traditional activities at which archivists already excel, such as teaching and outreach, cannot be dismissed as profoundly effective ways to mold the public perception of the profession. Julia Hendry makes a compelling case for how opening access to young learners can not only contribute to dynamic learning opportunities for the nonscholarly community, but also will "cultivate the next generation of archives users, donors and supporters," ${ }^{11}$ contributing to a better understanding of the archivist's role. A sound public relations program should necessarily

${ }^{25}$ Richard J. Cox, "Professionalism and Archivists in the United States," American Archivist 49, no. 3 (1986): 229-47; Arlene Schmuland, "The Archival Image in Fiction: An Analysis and Annotated Bibliography," American Archivist 62, no. 1 (1999): 24-73; Randall C. Jimerson, "Redefining Archival Identity: Meeting User Needs in the Information Society," American Archivist 52, no. 3 (1989): 332 40 .

${ }^{26}$ Elizabeth Yakel, "Thinking Inside and Outside the Boxes: Archival Reference Services at the Turn of the Century," Archivaria 49 (Spring 2000): 140-60.

${ }^{27}$ Francis X. Blouin, "Archivists, Mediation, and the Constructs of Social Memory," Archival Issues 24, no. 2 (1999): 101-12.

${ }^{28}$ Cosette N. Kies, Marketing and Public Relations for Libraries (Lanham, Md.: Scarecrow Press, 2003).

${ }^{29}$ Elsie Freeman Finch, ed., Advocating Archives: An Introduction to Public Relations for Archivists (Lanham, Md.: Scarecrow Press, 1994).

${ }^{30}$ Beth Whittaker and Lynne M. Thomas, Special Collections 2.0: New Technologies for Rare Books, Manuscripts, and Archival Collections (Santa Barbara, Calif.: Libraries Unlimited, 2009).

${ }^{31}$ Julia Hendry, "Primary Sources in K-12 Education: Opportunities for Archives," American Archivist 70 (Spring/Summer 2007): 114-29. 
include a plan for responding to negative attention, in addition to a consistent message touting the archives' value and impact on the community.

During the CAC crisis, Special Collections staff worked with the UIC Office of Public Affairs to develop press releases and talking points. Staff met with challenges in conveying a consistent message that addressed both the facts of the case and an explanation of our actions. Ultimately, the Office of Public Affairs and the university librarian provided the unified response for the institution, and media were referred to them for "on-the-record" comments. The CAC crisis could have been an opportunity for archival advocacy, and while we did not take advantage of this opportunity in the moment, we now understand firsthand the importance of getting out in front of a story so that our professional expertise and ethical positions can help shape the public's perception of archivists' work in all its complexities and importance.

\section{Conclusion}

This case study explores selected programmatic weaknesses made evident through a series of trying interactions with donors, researchers, and the media, and it has addressed the important role of collections management in support of an effective archival program. However, the most lasting lessons learned from these challenges involve a renewed sense of professional purpose, a reassertion of professional identity, and a redefined set of professional values now openly shared and actively shaped across the department.

The CAC crisis that UIC Special Collections handled in the summer of 2008 started with the online discovery of a collection over which we had not exerted sufficient control, exposing potential liabilities to stakeholders and focusing attention on weaknesses in our systems. The CAC crisis proved to be a reality check for the department. That a researcher can find a collection description, request access, interact with archives staff, and then blog about the experience all with the immediacy provided by his or her personal computer is both exciting-full of potential for promoting the use of archival collections, and cautionary-pointing to the increased responsibilities that archivists face in balancing the needs of donors, third-party privacy, and researchers interested in finding and understanding the past through archival collections.

It certainly behooves archivists to pay better attention to the intentional search strategies and serendipitous navigations employed by researcherstheir shortcomings, idiosyncrasies, and the roadblocks encountered along the way-so that we can make collection descriptions available in broader, more immediate, more obvious, and encompassing ways. However, just as important is the need for archivists to develop sound internal policies that take into account that collections, as well as policies, are now being discovered, 
circulated, promoted, and sometimes disparaged online. Making more collections accessible online exposes our work to a bigger and broader public and in ways over which we have increasingly less control. Archivists, now more than ever, need to be attuned to the risk management involved in providing widespread access to collections. In fact, Dennis Meissner states, "Zero risk is not an acceptable real-world model. [We] need to significantly elevate our risk tolerance as archivists. We are not responsible for ideal outcomes; we are only responsible for reasonable processes." 32

By recounting the unforeseen challenges surrounding this particular collection, we have tried to provide a road map for other archivists who find themselves in a position to translate and effectively handle legacy accessioning, processing, and publishing decisions. Several life cycles are at issue in this case study: the life cycle of the records themselves, the life cycle of the archival management of these records, and the life cycle of their discovery. The intersecting points of these three timelines are where UIC Special Collections staff has focused efforts at better addressing the weaknesses in our practices and at better articulating departmental policies and our professional roles, values, and obligations to both donors and researchers.

\footnotetext{
32 Dennis Meissner, untitled paper, Session \#501, Society of American Archivists Annual Meeting, Austin, Texas (August 2009) is footnoted in Mark A. Greene, "MPLP: It's Not Just for Processing Anymore," American Archivist 73, no. 1 (Spring/Summer 2010): 175-203.
} 


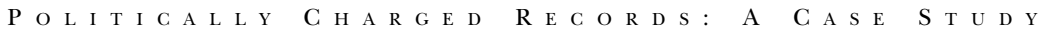

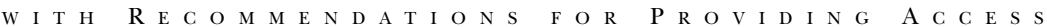

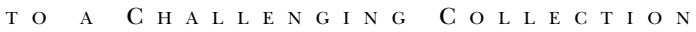

\section{Appendix I: UICSpecial Collections and University Archives Depart ment}

Decision Matrix for Sensitive Records in Manuscripts Collections

\begin{tabular}{|c|c|c|c|c|c|}
\hline $\begin{array}{l}\text { Type of } \\
\text { Record }\end{array}$ & $\begin{array}{l}\text { Type of } \\
\text { Information }\end{array}$ & $\begin{array}{l}\text { Applicable } \\
\text { Laws }\end{array}$ & $\begin{array}{l}\text { Ethical Access } \\
\text { Issues? }\end{array}$ & $\begin{array}{l}\text { Access } \\
\text { Guidelines }\end{array}$ & $\begin{array}{l}\text { Reproduction } \\
\text { Guidelines }\end{array}$ \\
\hline $\begin{array}{l}\text { Student and } \\
\text { Educational } \\
\text { Records }\end{array}$ & $\begin{array}{l}\text { PII (Personally } \\
\text { Identifiable } \\
\text { Information) }\end{array}$ & $\begin{array}{l}\text { Family } \\
\text { Educational } \\
\text { Rights \& } \\
\text { Privacy Act } \\
\text { (FERPA), 20 } \\
\text { USC § I232' }\end{array}$ & & $\begin{array}{l}\text { Records containing } \\
\text { any student infor- } \\
\text { mation other than } \\
\text { "directory informa- } \\
\text { tion" are restricted } \\
\text { for } 75 \text { years after } \\
\text { the records' crea- } \\
\text { tion. }\end{array}$ & $\begin{array}{l}\text { Photocopies of any } \\
\text { records less than } 75 \\
\text { years old will redact } \\
\text { information identi- } \\
\text { fying students, on } \\
\text { demand as needed. }\end{array}$ \\
\hline Health Records & $\begin{array}{l}\text { PHI (Personal } \\
\text { Health } \\
\text { Information) }\end{array}$ & HIPAA $^{2}$ & & $\begin{array}{l}\text { Access only } \\
\text { permitted "with } \\
\text { written } \\
\text { authorization, with } \\
\text { a waiver of } \\
\text { informed consent, } \\
\text { or in compliance } \\
\text { with HIPAA's "safe } \\
\text { harbor" or other } \\
\text { requirements."3 }\end{array}$ & \\
\hline Case Files & $\begin{array}{l}\text { PHI (Personal } \\
\text { Health } \\
\text { Information); } \\
\text { PII (Personally } \\
\text { Identifiable } \\
\text { Information); } \\
\text { Privileged } \\
\text { communication } \\
\text { or data }\end{array}$ & HIPAA & $\begin{array}{l}\text { Presumption of } \\
\text { confidentiality }\end{array}$ & $\begin{array}{l}\text { Restricted for } 75 \\
\text { years after creation. } \\
\text { Until } 75 \text { years have } \\
\text { passed, researchers } \\
\text { may access records } \\
\text { for aggregate data } \\
\text { but may not include } \\
\text { identifying } \\
\text { information in } \\
\text { publication. }\end{array}$ & $\begin{array}{l}\text { Photocopies of any } \\
\text { records less than } 75 \\
\text { years old will redact } \\
\text { information identi- } \\
\text { fying case subjects, } \\
\text { on demand as } \\
\text { needed. }\end{array}$ \\
\hline $\begin{array}{l}\text { Government } \\
\text { Records }\end{array}$ & $\begin{array}{l}\text { Privileged } \\
\text { communication } \\
\text { or data; PII } \\
\text { (Personally } \\
\text { Identifiable } \\
\text { Information) }\end{array}$ & $\begin{array}{l}\text { Privacy Act of } \\
1974,5 \text { USC, } \\
\text { §552a; }{ }^{4} \text { State } \\
\text { Privacy Laws }\end{array}$ & & $\begin{array}{l}\text { Closed for } 75 \text { years } \\
\text { after creation. } \\
\text { Records containing } \\
\text { SSN's should always } \\
\text { be redacted or } \\
\text { weeded, then } \\
\text { shredded. }\end{array}$ & $\begin{array}{l}\text { Photocopies of any } \\
\text { records less than } \\
75 \text { years old will } \\
\text { redact personally } \\
\text { identifying } \\
\text { information, on } \\
\text { demand as needed. }\end{array}$ \\
\hline $\begin{array}{l}\text { Financial } \\
\text { Records }\end{array}$ & $\begin{array}{l}\text { Account } \\
\text { numbers; PII } \\
\text { (Personally } \\
\text { Identifiable } \\
\text { Information) }\end{array}$ & & $\begin{array}{l}\text { Presumption of } \\
\text { confidentiality }\end{array}$ & $\begin{array}{l}\text { Bank account or } \\
\text { credit card } \\
\text { information should } \\
\text { be redacted OR } \\
\text { weeded, then } \\
\text { shredded, during } \\
\text { processing. }\end{array}$ & $\begin{array}{l}\text { Photocopies will } \\
\text { redact account } \\
\text { information, on } \\
\text { demand as needed. }\end{array}$ \\
\hline
\end{tabular}

\footnotetext{
I http://www2.ed.gov/policy/gen/guid/fpco/ferpa/index.html

${ }^{2}$ http://www.hhs.gov/ocr/privacy/hipaa/understanding/index.html

${ }^{3}$ Behrnd-Klodt, Navigating Legal Issues in Archives, 147.

${ }^{4}$ http://www.justice.gov/opcl/privacyact 1974.htm
} 


\begin{tabular}{|c|c|c|c|c|c|}
\hline $\begin{array}{l}\text { Type of } \\
\text { Record }\end{array}$ & $\begin{array}{l}\text { Type of } \\
\text { Information }\end{array}$ & $\begin{array}{l}\text { Applicable } \\
\text { Laws }\end{array}$ & $\begin{array}{l}\text { Ethical Access } \\
\text { Issues? }\end{array}$ & $\begin{array}{l}\text { Access } \\
\text { Guidelines }\end{array}$ & $\begin{array}{l}\text { Reproduction } \\
\text { Guidelines }\end{array}$ \\
\hline $\begin{array}{l}\text { Personnel } \\
\text { Records }\end{array}$ & $\begin{array}{l}\text { Privileged } \\
\text { communication } \\
\text { or data; PII } \\
\text { (Personally } \\
\text { Identifiable } \\
\text { Information) }\end{array}$ & & $\begin{array}{l}\text { Protect } \\
\text { presumption } \\
\text { that subject } \\
\text { would not } \\
\text { assume } \\
\text { identifying } \\
\text { information } \\
\text { would be made } \\
\text { available to } \\
\text { public } \\
\text { researchers. }\end{array}$ & $\begin{array}{l}\text { Closed for } 75 \text { years } \\
\text { after creation. } \\
\text { Records containing } \\
\text { SSN's should always } \\
\text { be redacted or } \\
\text { weeded, then } \\
\text { shredded. }\end{array}$ & $\begin{array}{l}\text { No photocopies } \\
\text { until } 75 \text { years from } \\
\text { creation have } \\
\text { passed. }\end{array}$ \\
\hline $\begin{array}{l}\text { Third-Party } \\
\text { Authored } \\
\text { Records }\end{array}$ & $\begin{array}{l}\text { Intellectual } \\
\text { property }\end{array}$ & Copyright $^{5}$ & & & $\begin{array}{l}\text { Alert researchers } \\
\text { that copyright } \\
\text { would need to be } \\
\text { cleared in the event } \\
\text { of any publication } \\
\text { or reproduction } \\
\text { outside of "fair use." }\end{array}$ \\
\hline $\begin{array}{l}\text { Personal } \\
\text { Correspon- } \\
\text { dence }\end{array}$ & $\begin{array}{l}\text { Privileged } \\
\text { communication }\end{array}$ & $\begin{array}{l}\text { Privacy torts: } \\
\text { - intrusion } \\
\text { - public } \\
\text { disclosure } \\
\text { of private } \\
\text { facts } \\
\text { - false light } \\
\text { - appropri- } \\
\text { ation }\end{array}$ & $\begin{array}{l}\text { Protect } \\
\text { presumption } \\
\text { that subject } \\
\text { would not } \\
\text { assume } \\
\text { potentially } \\
\text { damaging } \\
\text { information } \\
\text { would be made } \\
\text { available to } \\
\text { public } \\
\text { researchers. }\end{array}$ & $\begin{array}{l}\text { Risk management: } \\
\text { Identifying } \\
\text { information not } \\
\text { published/available } \\
\text { elsewhere may be } \\
\text { redacted OR } \\
\text { restricted for } 75 \\
\text { years, or weeded. }\end{array}$ & \\
\hline
\end{tabular}

\section{RESTRICTING Records in Manuscript Collections}

- $\quad$ Records may be restricted for a variety of reasons and to varying degrees. Restrictions may be imposed:

o by the donor, as stipulated in the deed of gift;

o to comply with current federal or state legislation;

o in cases when records have been deemed of an exceedingly sensitive nature, containing information that would infringe upon the affected party's right to privacy or otherwise contradict an expectation of confidentiality.

- A clear and consistent timeframe should be communicated to users of any records noted as restricted for when these records will be made available without restrictions. In many cases, restricted records can be made available after a sufficient amount of time has passed ensuring that the subject's right to privacy (which typically ends at death) has expired.

- Processing restricted records:

o Finding aids should include specific information about restricted materials including how these were handled during processing, where they are in the

\footnotetext{
${ }^{5}$ http://www.copyright.gov/title I 7/
} 


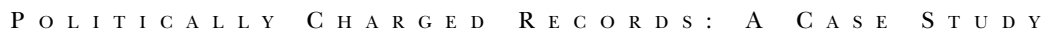

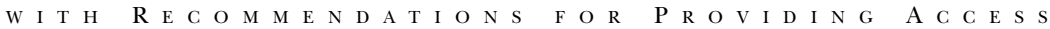

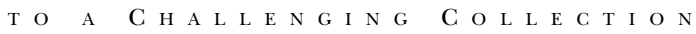

collection, and when the restriction(s) will be lifted. Boxes and folders containing restricted records should be labeled as such in the finding aid container list.

o Boxes containing restricted materials should be clearly marked as such (using the vibrant hot pink stickers), including the date when the restriction will be lifted.

o When processing, efforts should be made to isolate restricted records to separate boxes for the duration of the restriction. In some cases, it may be detrimental to disrupt the original or imposed context of restricted records by isolating or removing these to another box.

- In those cases when it is deemed important to retain original order, and thus keep restricted records alongside those without restrictions, redacted copies should be made available to researchers and originals set aside in a separate box.

- If original, restricted records are removed to another box, to ensure adequate evidence of the original or processor-imposed arrangement of these records, a separation note should be left in the original box or folder location. Additionally/Alternatively folders of restricted records removed from their original locations should bear their original box and folder numbers so that, upon the expiration of the restriction period, these folders can be re-inserted into their original locations.

o In some cases, especially for records consulted very frequently, a complete use set of redacted records should be created and housed in a box separate from the originals that can be paged directly to the reading room. 